\section{THE RELATIONSHIP BETWEEN METALS EXPOSURE AND METABOLIC SYNDROME AMONG ELECTROPLATING WORKERS IN TAIWAN}

${ }^{1}$ Ying-Chuan Wang*, ${ }^{2}$ Ping-Yen Chung, ${ }^{2}$ Ching-Huang Lai, ${ }^{1,2,3}$ Saou-Hsing Liou. ${ }^{1}$ Department of Family Medicine, Tri-Service General Hospital, National Defense Medical Centre, Taipei, Taiwan; ${ }^{2}$ School of Public Health, National Defense Medical Centre, Taipei, Taiwan; ${ }^{3}$ Division Of Method Development And Analysis, Institution of Occupational Safety and Health

\subsection{6/oemed-2018-ICOHabstracts.382}

Introduction Electroplating is required in printed circuit board (PCB) manufacturing factories. Electroplating workers may expose to metals in electroplating processes, and metals exposure will increase cellular oxidative stress and induce insulin resistance. Since insulin resistance is known to be associated with metabolic syndrome, we assessed the relationships between metals exposure and metabolic syndrome among electroplating workers.

Methods We recruited 172 electroplating workers and 84 office workers from 4 factories. Volunteers were required for overnight fasting, and we collected questionnaire, urine and blood samples in the morning. We used homeostasis model assessment of insulin resistance (HOMA-IR) to assess insulin resistance, and the criteria of metabolic syndrome was according to Taiwan Health Promotion Administration.

Result The study showed urinary concentration of vanadium $(0.11$ vs $0.07 \mu \mathrm{g} / \mathrm{g}$ creatinine, $\mathrm{p}<0.001)$, iron $(8.81$ vs $6.88 \mu \mathrm{g} / \mathrm{g}$ creatinine, $\mathrm{p}=0.03)$, nickel $(1.66$ vs $1.4 \mu \mathrm{g} / \mathrm{g}$ creatinine, $\mathrm{p}=0.02$ ), zinc (351 vs $298.2 \mu \mathrm{g} / \mathrm{g}$ creatinine, $\mathrm{p}=0.002$ ) in the exposed group are statistically significant higher than those of the reference group. By using the multivariate-linear regression, urinary nickel, arsenic, cadmium, lead showed significant positive correlation with HOMA-IR, and urinary zinc, arsenic, cadmium, lead showed significant positive correlation with fasting glucose. Besides, some urinary metal levels showed significant positive correlation with triglycerides, waist circumference, or blood pressure. Some of the urinary levels had negative correlation with high-density lipoprotein.

Conclusion Urinary nickel, copper, chromium, cadmium, lead are associated with metabolic syndrome. Elevating urinary concentrations of these five metals may induce metabolic syndrome.

\section{THE FACTORS WHICH INFLUENCES TO THE SERUM ADIPONECTIN LEVEL AMONG JAPANESE WORKERS WITH DECLINING RENAL FUNCTION}

\begin{abstract}
${ }^{1}$ Masatoshi Kawashima*, ${ }^{2}$ Tomoko Yokogawa, ${ }^{2}$ Akihiro Kuma, ${ }^{3}$ Taro Okazaki, ${ }^{4}$ Kazuhiko Enta. ${ }^{1}$ Tokyo Health Care Office, Health Care Centre, Central Japan Railway Company, Tokyo, Japan; ${ }^{2}$ Shizuoka Health Care Office, Health Care Centre, Central Japan Railway Company, Shizuoka, Japan; ${ }^{3}$ Nagoya Health Care Office, Health Care Centre, Central Japan Railway Company, Nagoya, Japan; ${ }^{4}$ Health Care Centre, Central Japan Railway Company, Nagoya, Japan
\end{abstract}

\subsection{6/oemed-2018-ICOHabstracts.383}

Introduction This study aimed to investigate factors which influences to the serum adiponectin level among Japanese workers with declining renal function.

Methods This study involved all participants who had undergone measurement of the serum adiponectin level at least one time at annual health examination during the period from 2008 to 2016 among Japanese workers in a railway company. We conducted analyses of participants with declining renal function. For those with serum adiponectin levels measured multiple times during this period, health examination data obtained during the year when the most recent level was measured were used for analysis.

The participants were classified into 4 categories according to eGFR. Categories G3a, G3b, G4, and G5 were 45-59, 30 $44,15-29$ and $<15 \mathrm{~mL} / \mathrm{min} / 1.73 \mathrm{~m}^{2}$; and the serum adiponectin level was obtained for each group.

Next, factors' affecting the serum adiponectin level was investigated among indices of lifestyle-related diseases and different lifestyles measured at health examination. The serum adiponectin level was used as a dependent variable, while eGFR, indices of lifestyle-related diseases, and different lifestyles were used as independent variables. Multiple regression analysis was performed to identify items significantly influences to the serum adiponectin level.

Results This study included 646 participants, and was $98.3 \%$ male. The mean serum adiponectin level was $8.6 \mu \mathrm{g} / \mathrm{mL}(1.8$ 32.5). The levels of the categories divided by eGFRs were 8.1 (G3a), 10.3 (G3b), 13.5 (G4), and 15.6 (G5). Multiple regression analysis identified four items as being significantly associated with the serum adiponectin level (standardised regression coefficient): eGFR (0.334), body mass index (0.241), the presence/absence of regular sleeping habits (0.114), and low-density lipoprotein (0.077).

Conclusions In the participants with declining renal function, the serum adiponectin level was significantly associated with some items. Estimated GFR showed the greatest standardised regression coefficient, indicating that eGFR strongly affects the serum adiponectin level.

\section{MATERNAL OCCUPATION IS ASSOCIATED WITH MATERNAL GLOBAL DNA (HYDROXY) METHYLATION IN THE SECOND TRIMESTER OF PREGNANCY}

${ }^{1,2}$ S Pauwels, ${ }^{1} \mathrm{M}$ Ghosh, ${ }^{1} \mathrm{RC}$ Duca, ${ }^{3}$ I Huybrechts, ${ }^{2,4} \mathrm{SAS}$ Langie, ${ }^{2} \mathrm{G}$ Koppen, ${ }^{5,6} \mathrm{R}$ Devlieger, ${ }^{1,7} \mathrm{~L}$ Godderis. ${ }^{1} \mathrm{KU}$ Leuven, Department of Public Health and Primary Care, Environment and Health, 3000 Leuven, Belgium; ${ }^{2}$ Flemish Institute of Technological Research (VITO), Unit Environmental Risk and Health, 2400 Mol, Belgium; ${ }^{3}$ International Agency for Research on Cancer, 150 Cours Albert Thomas, 69372 Lyon CEDEX 08, France; ${ }^{4}$ Hasselt University, Faculty of Sciences, 3590 Diepenbeek, Belgium; ${ }^{5} \mathrm{KU}$ Leuven-University of Leuven, Department of Development and Regeneration, 3000 Leuven, Belgium; ${ }^{6}$ University Hospitals of Leuven, Department of Obstetrics and Gynaecology, 3000 Leuven, Belgium; ${ }^{7}$ IDEWE, External Service for Prevention and Protection at Work, Interleuvenlaan 58, 3001 Heverlee, Belgium

\subsection{6/oemed-2018-ICOHabstracts.384}

Introduction Environmental factors, such as nutrition and occupational exposure can influence epigenetic marks like DNA methylation, which play a role in the development of chronic diseases.

Methods Data of the MAternal Nutrition and Offspring's Epigenome (MANOE) study was used to assess the effect of maternal occupation on maternal and infant DNA (hydroxy) methylation levels. Mothers were categorised in job categories according to the International Standard Classification of Occupations (ISCO). Maternal global DNA (hydroxy)methylation levels during each trimester of pregnancy and at delivery 